Olivares Mardones, Catalina Ayin.

Doctoranda, Investigadora en formación, Universidad de Barcelona, Departamento de Artes Visuales y Diseño.

Rubilar Medina, José Eugenio.

Doctorando, Investigador en formación, Universidad de Barcelona, Departamento de Artes Visuales y Diseño.

\title{
Desplazamiento del retrato fotográfico: tránsito del espacio íntimo al espacio social y público.
}

\section{Photographic portrait shift: Transition from the Intimate space to the social and public one.}

TIPO DE TRABAJO:

Comunicación Virtual.

PALABRAS CLAVE:

Retrato privado/público, desplazamiento, reproducción, masificación y discurso colectivo.

KEY WORDS:

Private/public portrait, shift, reproduction, widespread growth and collective discourse.

RESUMEN.

Esta indagación da cuenta de un recorrido que explora el desplazamiento del retrato fotográfico, particularmente dos casos de la cultura visual chilena; los retratos de detenidos desaparecidos (DD) de la dictadura cívico-militar y la figura del Capitán Arturo Prat Chacón. En estos dos modos, el retrato es un código visual que abre cuestionamientos en torno a quién ve el retrato, cómo se ve el mismo y qué lugar ocupan. En ambos casos el retrato fotográfico transita desde espacios familiares, hacia espacios de hiperrepresentación global en el que se inscriben nuevos regímenes de significación. El código del retrato es transición y transacción de discursos que van de lo privado a lo público (lo local y lo global), operando como símbolos que producen significados. El retrato adquiere entonces una condición orgánica que se tiñe del propio devenir social y levanta nuevas tensiones en la imagen.

\section{ABSTRACT.}

This research tells us about a journey that explores the photographic portrait displacement, particularly two cases of the Chilean visual culture; The portraits of disappeared detainees (DD) of the civic-military dictatorship and the figure of Captain Arturo Prat Chacón. In these two ways, the portrait acts as a visual code that opens questionings about who is watching it, how does he look at himself and what place do they take. In both cases the photographic portrait circulates from familiar spaces towards global hyper representation spaces, in which new regime of significance are enrolled. The portrait code are transition and discourse transaction, which are from the private to the public one (local and global), acting as symbols which produce meanings. The portrait acquires, then, an organic condition painted of social evolution and it rises new tensions to the image. 


\section{CONTENIDO.}

\section{Introducción.}

La imagen fotográfica se ha abordado históricamente como un objeto de interpretación, memoria y realidad al que se han añadido lecturas que desembocan en análisis históricos, políticos y culturales. Esta indagación se concentra en la fotografía, específicamente en la variante del retrato fotográfico, entendido este como "forma simbólica" (Burke, 2005) que, a través de estrategias políticas de reproductibilidad, transita del espacio íntimo (familiar) al espacio público del paisaje social. Desde esta perspectiva, repensaremos el retrato fotográfico desde su origen íntimo relativo a la descripción de un individuo, hasta su lugar en la inscripción de identidad social (Tagg, 2005).

Damos cuenta de dos casos temporalmente distintos, pero significativamente críticos respecto a su origen íntimo-privado y su tránsito hacia el espacio público. El primero corresponde al retrato del DD de la dictadura militar chilena (1973-1991), que transita como código que individualiza al sujeto con sus características personales, a un retrato cuya identidad visual (la fotografía con rigurosidad) se disuelve para dar paso a un símbolo que aglutina la idea global de sujetos que han desaparecido forzadamente. El segundo caso navega en el retrato fotográfico decimonónico del Capitán Prat (1848-1879) que, en su origen privado, presenta la distinción del estatus militar propio de la época, para reconfigurarse y transitar a la esfera pública como hombre de armas mitificado en la figura del héroe.

\section{De la fotografía íntima de un ser querido, al retrato del Detenido Desaparecido (DD) como reclamación colectiva.}

Los retratos de víctimas de desaparición forzada en la dictadura militar chilena, los comprendemos como símbolos que desplazan la idea de retrato acabado hacia una síntesis visual del rostro. Debido a su reiterada reproducción en el tiempo la imagen se transforma, pasando de la presentación del retrato de un individuo en un espacio familiar, a uno que pertenece al tejido social y constituye una reclamación colectiva.

La dictadura cívico-militar se inicia con el golpe de estado el 11 de septiembre de 1973, cuando las Fuerzas Armadas de Chile asumen el poder Ejecutivo, Legislativo y Constituyente. En 1990 finaliza la dictadura, luego de un proceso que consignó crímenes de lesa humanidad, la modificación de la constitución (aún vigente) y la instalación del modelo neoliberal. Los agentes del régimen tenían como prácticas detenciones arbitrarias, torturas en centros clandestinos, y en varios casos, la desaparición forzada de sus prisioneros.

En este contexto, los familiares de los desaparecidos y diferentes organizaciones sociales, sistematizan la información de las víctimas para ser inscritas en recursos de amparo y protección. Este trabajo es guiado en un comienzo por el Comité Pro Paz (1973) integrado por parroquias católicas, que más tarde pasa a ser la Vicaría de la Solidaridad (1976), espacio que dio apoyo social y legal a los familiares de las víctimas. El tejido social que trabaja estrechamente con estos dos organismos, es la Agrupación de Familiares de Detenidos Desaparecidos (AFDD), quienes reproducirán la imagen de sus seres queridos, portándolas en diversas manifestaciones sociales.

Por el sistemático esfuerzo de la AFDD de mantener la búsqueda de sus seres queridos, las fotografías de los DD forman parte del imaginario colectivo chileno de reivindicación. Son imágenes que han alcanzado un recorrido, donde la fotografía del DD ha sostenido un proceso de desarrollo y cambio, tanto en su vinculación con el espacio público, como en su representación visual y simbólica. Consecuencia de los anterior surge la pregunta: ¿Cómo el retrato del DD configura una reclamación colectiva en un régimen de significado visual?

En las imágenes ${ }^{1}$ utilizadas por la AFDD a inicios de la dictadura, distinguimos un tono íntimo. Queda evidenciado el origen privado de la fotografía, por su estética y pequeño formato de álbum familiar. También íntima, porque es el retrato de un ser amado que enuncia un vínculo y una historia en común con la persona que carga la imagen. Fotografía que, en la necesidad de visibilizarse, se vierte al terreno público en un gesto que manifiesta una doble ausencia: el retrato retirado del álbum, y la imagen que enuncia la ausencia del cuerpo desaparecido. Aquí la imagen resiste en el cuerpo de los que buscan.

\footnotetext{
${ }^{1}$ [fotografía 1] en: BECERRA, G.; SIERRA, S. \& DIAZ, V. 1997. 20 años de historia de la Agrupación de Familiares de Detenidos desaparecidos de Chile: Un camino de imágenes, Santiago-Chile.
} 


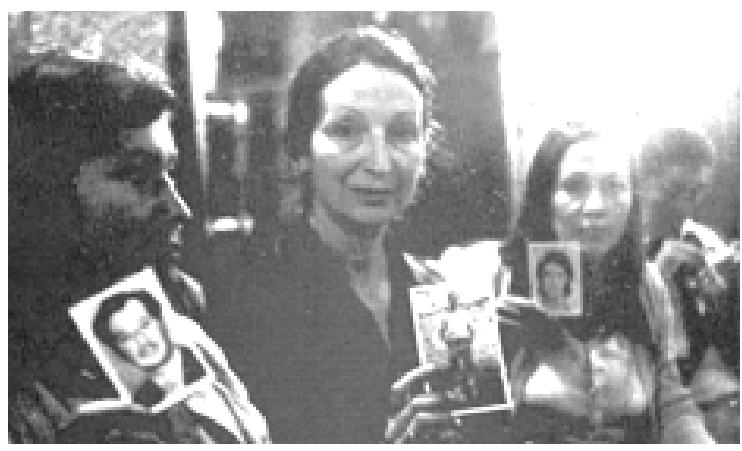

1. Este es el momento en que Chile conozca la verdad, 1977.

En los años 1977 y 1978 los familiares realizan manifestaciones de huelgas de hambre ${ }^{2}$, donde cada familiar lleva consigo la fotografía de su ser querido desaparecido. Por su vulnerable estado la AFDD se manifiesta en lugares protegidos y las fotografías se mantienen en espacios privados, donde la observación de los retratos sigue siendo de poca masividad.

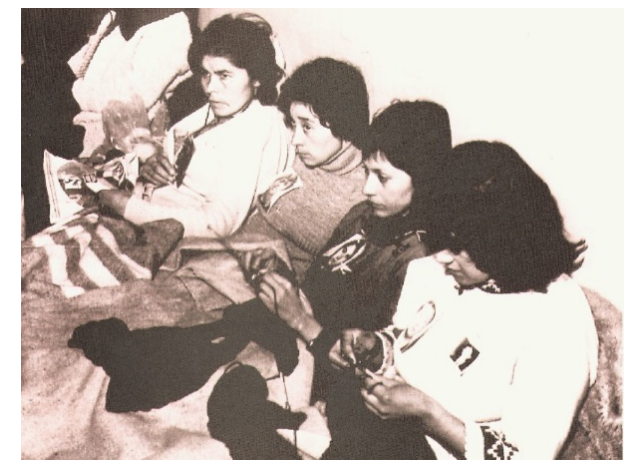

2. Una vez más nuestra vida por la verdad, 1978.

Hacia 1979, una de las manifestaciones de la AFDD ocupa terreno público y los retratos de los DD comienzan a ser parte del paisaje urbano. Como protesta ${ }^{3}$ los familiares se encadenan en el Tribunales de Justicia, siendo fotografiados con sus retratos en medios de prensa. Este gesto de extroversión de la imagen al espacio público se transforma en un "a partir" que inicia el recorrido de estas fotografías. Así como un mirador que posibilita nuevas observaciones de la imagen con las que hoy podemos contar. Desde este "aqui", el retrato se vierte al espacio público como símbolo de reivindicación y justicia político-social. Aunque aún en este momento de reclamación la imagen utilizada por la AFDD es pequeña (formato álbum), consideramos que "el salir" a lo público, es el acto que exige a la imagen cambiar sus características visuales para ser obligadamente reconocibles.

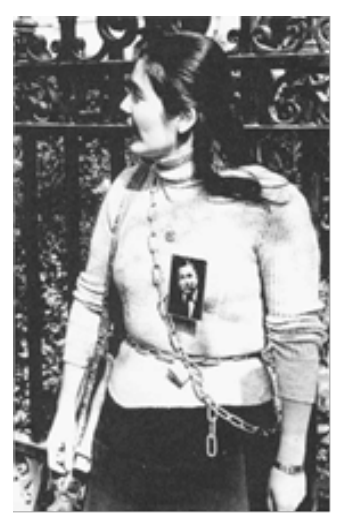

\section{Hija de DD encadenada en Tribunales de Justicia, 1979.}

\footnotetext{
${ }^{2}$ [fotografía 2] en: BECERRA, G. [et.al:].

${ }^{3}$ [fotografía 3] en: BECERRA, G. [et.al.].
} 
Avanzada la política del terror en los $80^{\prime}$, la desaparición de personas ya no puede ser falseada. Las agrupaciones sociales lideradas por la AFDD sistematizan diversas manifestaciones que resultan más masivas ${ }^{4}$ pese a los costos políticos/humanos que podrían significarles.

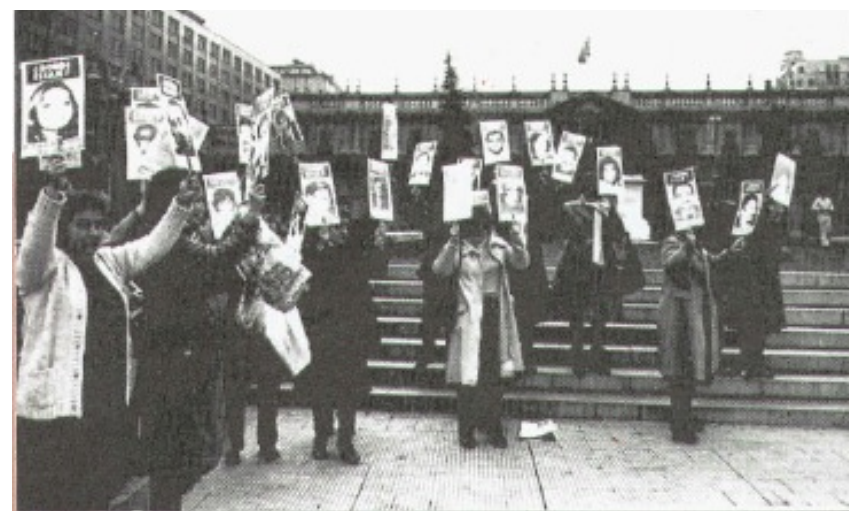

4. AFDD frente al Palacio de Moneda, 1982.

Las características de las imágenes de los DD se modifican, los formatos se amplían y se incorpora texto. Manteniéndose sí la idea de retrato que no representa una imagen violenta, pues no instan a cerrar los ojos para evitar su contemplación debido a la presencia de una imagen cruda. En su defecto, son imágenes que proponen el se busca: ¿reconoce este rostro? y sugieren por tanto la mirada. Aquí observamos el momento trascendental de "sentar la vista", que potencialmente puede conseguir un efecto político. Detener la mirada en una imagen que acompaña un acto de protesta, propone sustentar una interpretación que va más allá de la propia imagen. Acercándonos a "lo intolerable" de Rancière (2010), la imagen es real pero no desde una crudeza inaguantable que haga que no queramos verla. Por el contrario, al Ser la imagen en un sentido íntimo (un familiar querido), la fotografía no responde a un régimen de exhibición como una pieza más de un flujo de imágenes que resulta desbordado, por tanto, invisible para su interpretación.

La reclamación de los desaparecidos se mantiene en las calles con la imagen y con la pregunta que abre el diálogo con el no-familiar: ¿dónde están? La pregunta requiere de un intercambio reflexivo sobre el paradero de los cuerpos. Imagen más texto consigue desde nuestro punto de vista, la invitación de Didi-Huberman (2013) a "abrir los ojos". La imagen no prescinde del sujeto, por el contrario, lo "trae aquí" de modo sutil para denunciar serenamente la violencia que los hizo desparecer. En un ejercicio devenido que Didi-Huberman concreta en una pregunta "¿Cómo desarmar las defensas, las protecciones, los estereotipos, la mala voluntad, las políticas del avestruz de quien no quiere ver?" (р.19). Es la imagen "tolerable" (Ranciere, 2010) y que se puede ver, es la imagen que realmente podemos mirar; es la ampliación y reiteración del retrato fotográfico, su relación con el espacio público, y la pregunta que la acompaña, es la tensión que moviliza al observador a desarmar las defensas, lo que le permite "ver" ${ }^{5}$.

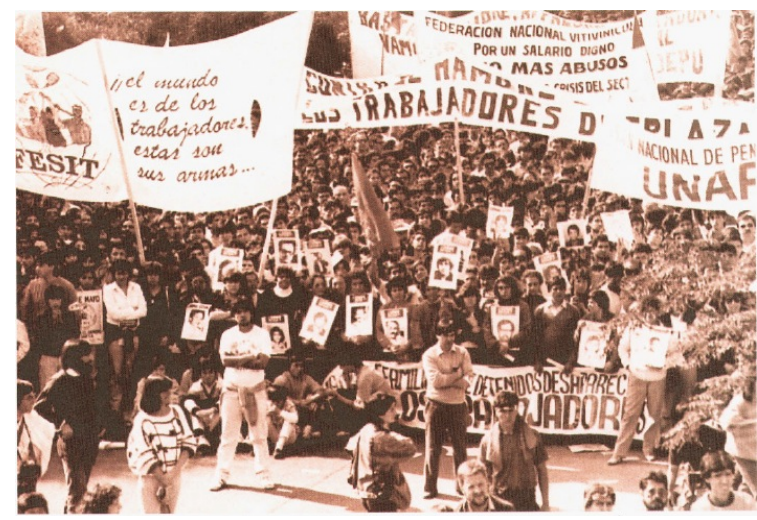

5. Parque O’Higgins la AFDD conmemora Día internacional del Trabajo, 1983.

\footnotetext{
4 [fotografía 4] en: BECERRA, G. [et.al.].

5 [fotografía 5] en: BECERRA, G. [et.al.]
} 
Visualmente el rostro de los DD se desgasta, la reproducción técnica y la ampliación de la imagen le restan rigor a la representación del rostro, sustrayéndole la identidad individual ${ }^{6}$. Ahora, la fotografía de un determinado sujeto ya no es una, y ya no es cargada sólo por su familiar directo, ahora un mismo retrato es portado por distintas personas en un gesto de exigencia que se hace colectivo. La insistente reproducción de la imagen permite exaltar la carga política del retrato ${ }^{7}$ en un discurso de reclamación masificado, donde la imagen original complementa su significado en su falta de precisión visual. Manifestarse con un retrato que ya no corresponde al sujeto con nombre y apellido, devela que quien sea el retratado, éste no puede haber dejado de estar.

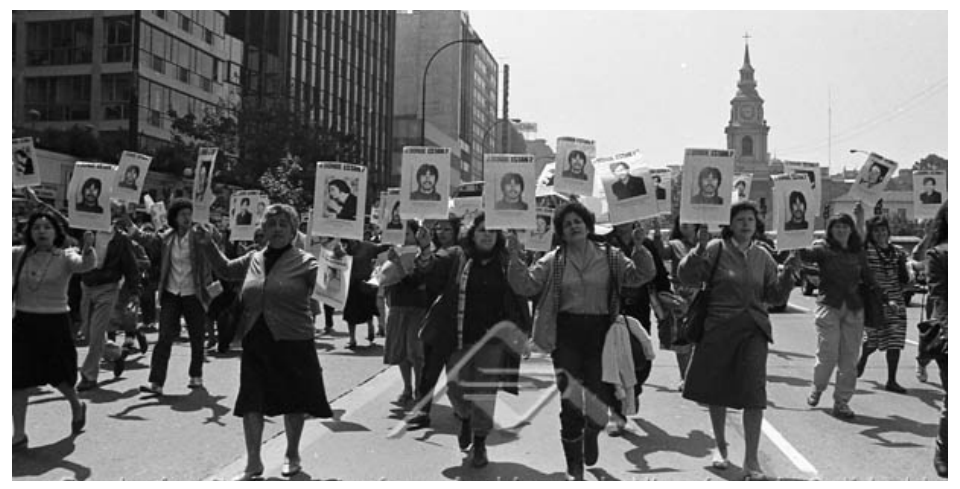

6. La AFDD por cinco desaparecidos, 1987.

La reproducción de la imagen desde la noción de reproductibilidad (Benjamin, 2003) supone la pérdida del aura, no obstante, la fuerza y el valor simbólico de la imagen del DD se desprende de la reiteración. Aquí el "aura de la imagen" ese "entretejido muy especial del espacio y tiempo: aparecimiento único de una lejanía" (p.43) no se destruye en la medida en que se reproduce la imagen. Al contrario, es la reiteración lo que potencia su valor político-ritual. Como tejido social todos podemos/debemos cargar con esta imagen que reclama justicia social. Así, lo que para Benjamin podría ser el “(...) condicionamiento social de la actual decadencia del aura (...) con el surgimiento de las masas y la intensidad creciente de su movimiento." (p.47), es lo que dota de discurso a la reclamación políticocolectiva, donde la no autenticidad de la imagen en su repetición como símbolo, se intensifica demandando verdad. Aquí emerge la fundamentación política de la imagen: “(...) si el criterio de autenticidad llega a fallar ante la reproducción artística, es que la función del arte se ha trastornado. En lugar de su fundamentación en el ritual, debe aparecer su fundamentación en la praxis, a saber: su fundamentación en la política" (p.51).

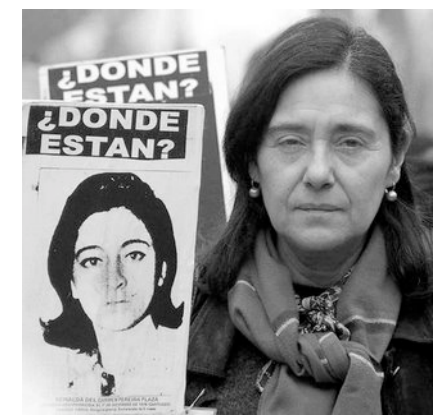

\section{Manifestante miembro de la AFDD, 1991.}

Al dislocar el concepto de pérdida del aura, hallaremos la ganancia que tiene la imagen entorno a su fundamentación en la práxis, es decir, en lo político. Aquí el retrato se amalgama con las demandas sociales, asumiendo sus cambios visuales para la creación de un discurso colectivo, para la construcción de un hoy (o de "muchos hoy", según sea la vereda en la que nos encontremos). Esta idea la elaboramos no sólo a partir del pasaje tonal que ha sostenido la imagen del $\mathrm{DD}^{8}$, sino también, con otro ejemplo de la cultura visual chilena, que se toma del mismo argumento, pero que transita en otros valores propios de la construcción de una sociedad, cuya imagen consigue el valor de la recontextualización, pues el lenguaje en el que se mueve la fotografía, es el lenguaje de los acontecimientos (Berger, 2006). Tal es el caso del retrato fotográfico de Arturo Prat Chacón.

\footnotetext{
${ }^{6}$ [fotografía 6] en: Archivo iconográfico de la Vicaria de la Solidaridad. Fotografía, Santiago-Chile.

${ }^{7}$ [fotografía 7] en: http://chileddhh.blogspot.com.es/p/agrupacion-de-detenidos-desaparecidos.html

8 [fotografía 8] en: http://chileddhh.blogspot.com.es/p/agrupacion-de-detenidos-desaparecidos.html
} 


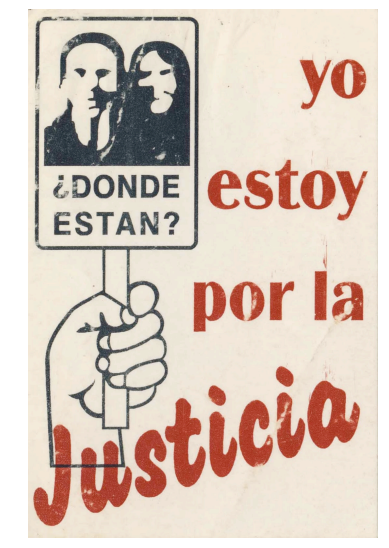

8. Logo Agrupación de Familiares de Detenidos Desaparecidos.

\section{Del retrato decimonónico de un Capitán, a la masificación de la imagen de un héroe.}

El retrato fotográfico es una imagen que alberga sentido de permanencia temporal de un sujeto, permanencia que le permita declarar el propio legado a la familia y al entorno social directo. Es el caso del retrato fotográfico decimonónico el que mantuvo los convencionalismos del retrato pictórico (Burke, 2005) y apeló a rendir homenaje a individuos de status creciente. Como lo plantea Bourdieu (2003 p.142), el retrato presenta "personajes de frente, en el centro de la imagen, de pie, firmes, a una distancia respetuosa, inmóviles y en actitud digna". Si bien en ello había una función social que buscaba proyectar virtudes, el retrato seguía perteneciendo al espacio íntimo-privado de las familias. El retrato fotográfico decimonónico en Chile era un privilegio de oficiales militares, políticos y aristocráticos, es el caso del Capitán de Fragata Arturo Prat Chacón ${ }^{9}$ (1848-1879) caído en combate durante la Guerra del Pacífico (conflicto bélico -1879-1883- que enfrento a Chile con Perú y Bolivia).

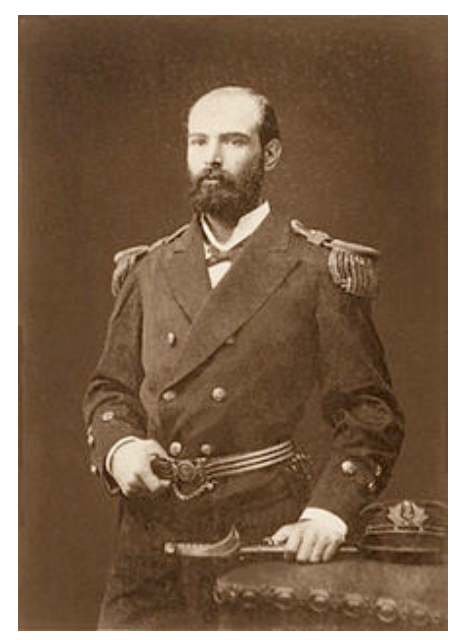

\section{Capitán de Fragata Arturo Prat Chacón.}

Finalizando la guerra, la imagen privada (el retrato fotográfico de Prat) es desplazado al espacio público en un gesto político que expande la figura moral que visualiza un héroe. Arévalo (2013) señala que la construcción de la figura heroica de los militares en esta guerra presenta dos características comunes: sus líderes mueren en las batallas y los combates significaron derrotas militares. En este escenario bélico, "los gobiernos entendieron que la inversión en materia del arte, tanto en las referencias de la escultura monumental como en la pintura histórica y alegórica, eran fundamentales. Este arte debía subyugar, enternecer y provocar sentimientos de afinidad con la heroicidad" (Martínez, 2008 p.101). Del retrato de Prat se realizaron grabados, pinturas y esculturas que visualizaban el perfil mitificado del Capitán, exponiéndolo según Subercaseux (2002) como una figura casi cristológica, como un santo secular acompañado de símbolos

${ }^{9}$ [fotografía 9] en: http://www.armada.cl/armada/tradicion-e-historia/biografias/p/agustin-arturo-prat-chacon/2014-01-20/111911. 
y metáforas. La reproductibilidad de la imagen, encomendada desde las políticas institucionalizadas, exaltan la figura de Prat ${ }^{10}$ en torno a virtudes y metel triunfo de las cualidades morales, estrategias de representación propias de los "arquetipos de santidad, que activan memorias locales y que engalanan los actos cívicos, en las esferas del poder simbólico de un héroe patrio" (Díaz, 2012 p.326).

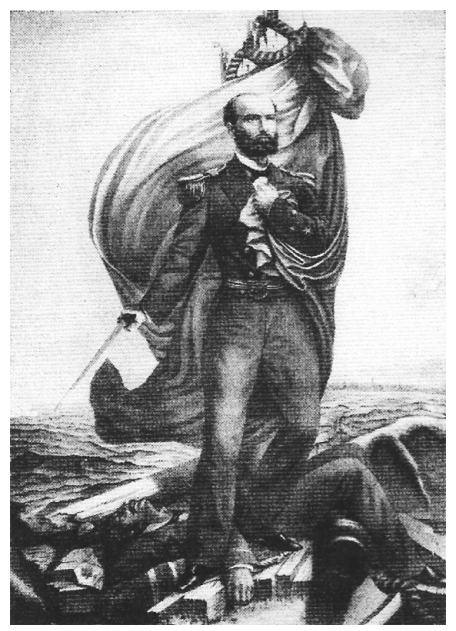

\section{Arturo Prat Chacón, 21 de mayo de 1879.}

En Chile, cada 21 de mayo (festivo nacional) se recuerda el "Combate Naval de lquique" batalla que recuerda la muerte de Prat mediante la organización de desfiles cívico-militares entre miembros de la Armada y los estudiantes de los establecimientos escolares públicos. Tanto desfiles como conmemoraciones cumplen una función de "ritual-cívico con fines disciplinadores y pedagógicos" (Aguirre, 2005, p.150), donde la imagen de Prat "actúa sobre dos líneas fundamentales, por una parte, en el espíritu de construcción identitaria para la formación cívica, y por otra, en la educación del ciudadano en los preceptos de la moral burguesa" (Cortés, 2009, p. 1234).

Pero también existen representaciones que tienen una dimensión más "popular", (Decante, 2015), y el retrato de Prat figura tanto en etiquetas, portadas, carátulas, sellos postales, afiches y logotipos, etc. Por ejemplo, su retrato ha aparecido en billetes desde que se comenzó a utilizar el papel moneda en Chile, presente aún en la actualidad en el billete de diez mil pesos. Aquí la reproductibilidad técnica de la imagen se despliega en distintos formatos de difusión y circulación visual y material. Se han elaborado álbumes, historietas, comics y películas que son parte de una cultura visual que se extiende a la perdurabilidad pública de la imagen ${ }^{11}$ de Prat en espacios discursivos públicos que evidencian la relación entre imagen, percepción y producción de ideología (Ribalta, 2008).

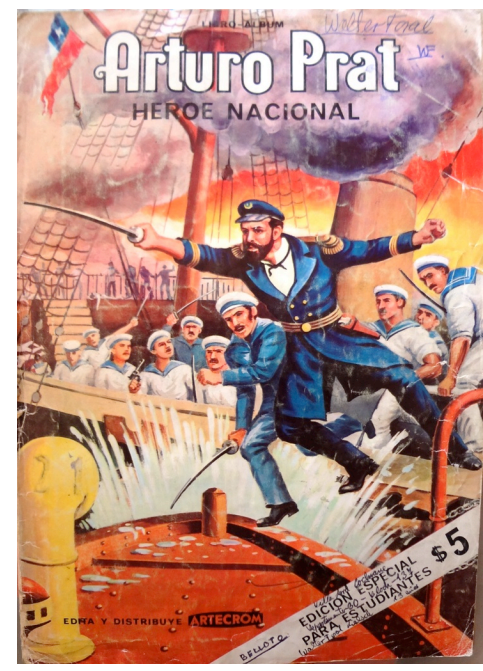

11. Portada de Álbum "Arturo Prat, Héroe Nacional", Artecrom, 1978.

\footnotetext{
${ }^{10}$ [ilustración 10] en: http://www.museohistoriconacional.cl/618/w3-article-28595.html

${ }^{11}$ [ilustración 11] en: http://chile-arturo-prat.blogspot.com.es/2013/08/blog-post_9215.html
} 
En este sentido, la imagen resulta una de las herramientas más eficaces de aprendizaje y de control, que a la par con otras construcciones culturales, nos enseñan cómo son los héroes, cómo lucen las personas "malas", y a la vez también qué es aquello que amerita ser expuesto y reconocido (Raposo, 2009).

La digitalización, como fenómeno de reproductibilidad, ha desprendido al retrato de su materialidad física, quedando limitada su "existencia" al visionado de las pantallas (Argerich, 2015) como material visual recontextualizado, resignificado y proliferado. Esto se enmarca en los fenómenos de "hiperconexión e hiperrelacionalidad, o comportamientos virales de contagio, todo aquello que se nombra como cibercultura" (Fuentes, 2015, p.5). En este cibercontexo público, los memes recogen la imagen institucionalizada del héroe para escenificar otros discursos, por ejemplo, encontrar a Prat como seleccionado de futbol ${ }^{12}$. En la elaboración de los memes destaca el poder de intervención que tienen los usuarios sobre las imágenes que circulan inscribiéndolas en nuevos modelos de significación.

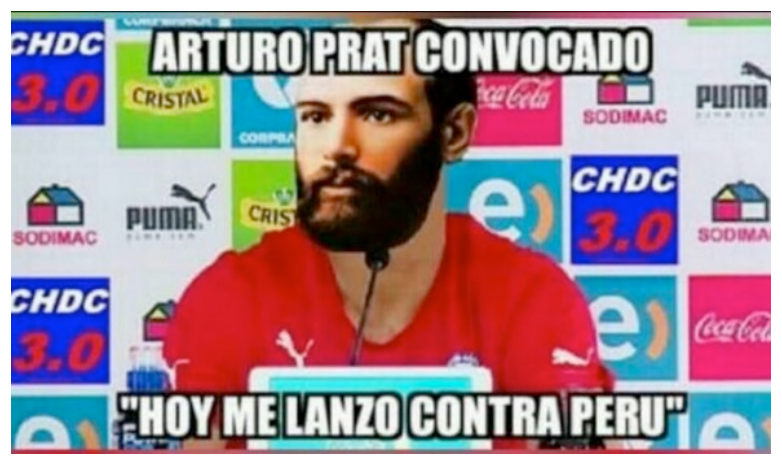

12. Meme: "Arturo Prat Convocado- Hoy me lanzo contra Perú".

\section{Palabras al cierre.}

Esta fundamentación política de la imagen a partir de la praxis (Benjamin, 2003) reafirma nuestra mirada del retrato como desplazamiento. La imagen del DD es política en tanto se vuelve una reclamación colectiva de justicia y verdad. La imagen como retrato en su origen no carga con tal acento político, pues corresponde a un retrato de un contexto íntimo y privado, siendo el gesto de desplazamiento a lo público en su insistente reproductibilidad lo que denota su carga política.

El desarrollo sostenido de las imágenes-retratos de los DD, supone un cambio en su visualidad. En un comienzo, las imágenes procedentes del álbum colgaban del pecho de los familiares que exigen el paradero de las víctimas. Transcurriendo la dictadura, las movilizaciones sociales que demandan información sobre los desaparecidos se expanden y los retratos empiezan a ser parte del paisaje urbano. En el espacio público las imágenes amplían su formato en un gesto de necesaria visibilidad que se acentúa con la incorporación de texto. El recorrido de las imágenes-retratos pasa de la presentación de un individuo en la exigencia familiar, hacia un discurso colectivo en un nuevo régimen de significado, donde converge la exigencia de un tejido social que puede o no ser familiar de la víctima. La nueva imagen retrato del DD finalmente es una exigencia que nos convoca en tanto seres humanos, en tanto contamos aún con un sentido de humanidad; los DD nos faltan a todos, no sólo a sus familiares. La imagen retrato es hoy, una reclamación colectiva.

La reproductibilidad técnica propone una insistencia de la imagen para la construcción de significados, en el caso de la fotografía decimonónica de Prat hay un desplazamiento del retrato del espacio privado al público planteado como una estrategia políticoideológica para mitificar y construir la imagen de héroe nacional. Imágenes de un amplio abanico visual y representacional que contienen metáforas nacidas de la necesidad ideológica de construir significados en el discurso de identidad nacional. Ahora la masificación del retrato a partir de su digitalización, reconfigura y crea nuevos discursos en torno al héroe.

En los casos expuestos, el énfasis radica en la propia capacidad del retrato para significar más de una cosa, y fundamentar su carga en "lo político", más allá de un cuerpo presentado visualmente como retrato inocuo. Es una imagen masificada que propone un discurso social y socializado, por eso quisiéramos quedarnos con la planteado por Burke (2005), al hacer notar que el "retrato es una forma simbólica" (p.30) que se desplaza y se expande. Es un retrato cuya insistente reproducción propone un devenir en la imagen formal, la que de alguna manera se instala en el contexto social a pesar del paso del tiempo, debido a su construcción discursiva que se entrama con la exigencia social (caso DD) y con las resignificaciones de los discursos alegóricos institucionalizados (caso Prat).

\footnotetext{
12[ilustración 12] en: https://www.civico.com/santiago/noticias/chile-versus-peru-el-partido-comenzo-a-traves-de-los-memes
} 
Olivares Mardones, Catalina Ayin; Rubilar Medina, José Eugenio

Desplazamiento del retrato fotográfico: transito del espacio íntimo al espacio social y público

III CONGRESO INTERNACIONAL DE INVESTIGACIÓN EN ARTES VISUALES :: ANIAV 2017 :: GLOCAL [codificar, mediar, transformar, vivir] http://dx.doi.org/10.4995/ANIAV.2017.5230

\section{FUENTES REFERENCIALES.}

AGUIRRE, C. 2005. "Monumentos, fiestas y desfiles en Iquique. Nacionalismo en 1900, patrimonio en el 2000". Si Somos Americanos Revista de Estudios Transfronterizos, vol.7, n² pp.139-153. ISSN: 0718-2910. [Última consulta: 18 abril 2017]. Disponible en: http://www.redalyc.org/articulo.oa?id=337930323008

ARÉVALO, A. 2013. "El rol de la prensa escrita en la reproducción de la violencia en el conflicto entre Chile y Perú. Propuestas de paz desde la comunicación". Revista de Estudios Sociales, n48, pp. 151-164. ISSN-e: 0123-885X. [Última consulta: 18 abril 2017]. Disponible en: http://www.redalyc.org/articulo.oa?id=81530018012

ARGERICH, I. 2015. "Fotografía y archivo". Fotocinema, Revista cientifica de cine y fotografía, n¹0, pp. 101-117. ISSN 2172-0150. [Última consulta: 18 abril 2017]. Disponible en:

http://www.revistafotocinema.com/index.php?journal=fotocinema\&page=article\&op=view\&path\%5B\%5D=299

BENJAMIN, W. 2003. La obra de arte en la época de la reproductibilidad técnica. México, D.F: Ítaca. ISBN: 9789687943480.

BERGER, J. 2006. Sobre las propiedades del retrato fotográfico. Barcelona: Gustavo Gili. ISBN: 84-252-2055-6.

BOURDIEU, P. 2003. Un arte medio. Ensayo sobre los usos sociales de la fotografía. Barcelona: Editorial Gustavo Gili. ISBN: 84-252-19434.

BURKE, P. 2005. Visto y no visto. El uso de la imagen como documento histórico. Madrid: Ed. Crítica. ISBN: 84-8432-631-4.

CORPORACIÓN NACIONAL DE REPARACIÓN Y RECONCILIACIÓN 1996. “Informe sobre calificación de víctimas de derechos humanos y de la violencia política". Santiago: CNRR. [Última consulta: 18 abril 2017]. Disponible en: http://www.cedocmuseodelamemoria.cl/wpcontent/uploads/2011/12/Informe_CNRR.pdf

CORTÉS, G. 2009. "Monumento al Roto...piojento: La construcción oligárquica de la identidad nacional en Chile". Arbor. Ciencia, Pensamiento y Cultura, vol.185, n740, pp. 1231-1241. ISSN: 0210-1963. [Última consulta: 18 abril 2017]. Disponible en: http://arbor.revistas.csic.es/index.php/arbor/article/viewArticle/391

DECANTE, S. 2015. "De naves quemadas y otras borracheras: la revisitada figura (anti)heroica de Arturo Prat". Revista Iberoamericana, vol.71, n²13, pp. 1191-1202. ISSN 0034-9631. [Última consulta: 18 abril 2017]. Disponible en: http://revistaiberoamericana.pitt.edu/ojs/index.php/Iberoamericana/article/view/5413

DíA , A. 2012. “Reseña de La Guerra de 1879 y la Integración: desde la enseñanza de la Historia de Patricio Rivera Olguín”. Historia, 1(45), pp. 325-328. ISSN 0717-7194. Disponible en: http://www.scielo.cl/scielo.php?script=sci_arttext\&pid=S0717-71942012000100031

BECERRA, G.; SIERRA, S. \& DIA , V. 1997. 20 años un camino de imágenes. Santiago de Chile: Corporación Agrupación de Familiares de Detenidos Desaparecidos. ISBN 956-7677-00-X.

DIDI-HUBERMAN, G. 2013a. Cuando las imágenes tocan lo real. Madrid: Círculo de Bellas Artes. ISBN: 9788487619748.

2013b. “Cómo abrir los ojos”. En: Desconfiar de las imágenes. Buenos Aires: Caja negra, pp. 13-35. ISBN: 9789871622184

2008c. Cuando las imágenes toman posición. El ojo de la historia 1. Madrid: A. Machado Libros. ISBN: 978-84-7774-823-6.

MARTíNE , J. 2008. "El develamiento de la visualidad heroica, el sacrificio de Prat”. Intus-Legere Historia, vol.2, n², pp. 91-107. ISSN: 0718-5456. [Última consulta: 18 abril 2017]. Disponible en: http://intushistoria.uai.cl/index.php/intushistoria/article/view/100

RAPOSO, G. 2009. "Narrativas de la imagen: Memoria, relato y fotografía”. Revista Chilena de Antropología Visual, n¹3, pp. 79-103. ISSN 0717-876X. [Última consulta: 18 abril 2017]. Disponible en: http://www.rchav.cl/imagenes13/imprimir/raposo.pdf

RANCIÈRE, J. 2010. El espectador enmancipado. Castellón: Ellago. ISBN: 978-84-96720-92-3

SUBERCASEAUX, B. 2002. "Nación, héroes y arte (ruido, demasiado ruido)". Cyber Humanitates, n²5. ISSN 0717-2869. [Última consulta: 18 abril 2017]. Disponible en: http://www.revistas.uchile.cl/index.php/RCH/article/viewArticle/5628/5496

TAGG, J. 2005. El peso de la representación. Ensayos sobre fotografías e historias. Barcelona: Editorial Gustavo Gili. ISBN: 84-252-1999-X. 